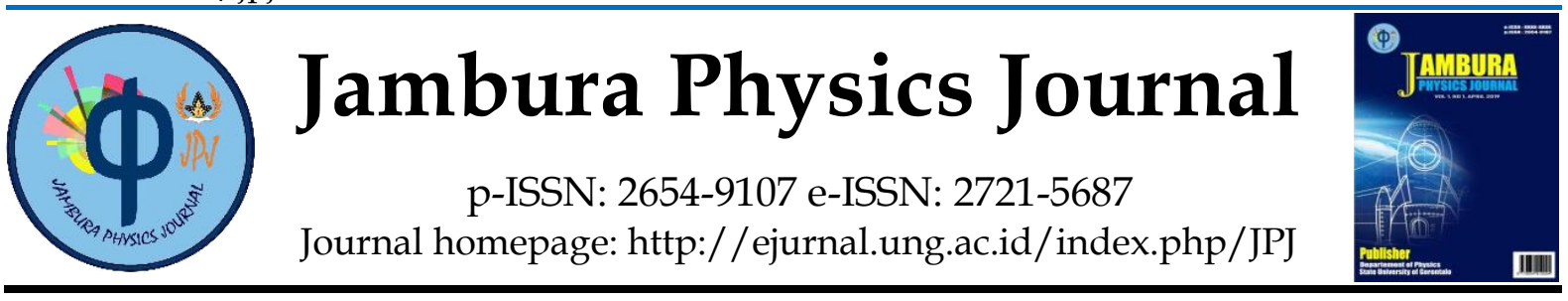

\title{
PENGEMBANGAN PERANGKAT PEMBELAJARAN IPA TERPADU PADA MATERI ENERGI UNTUK SISWA KELAS VII MADRASAH TSANAWIYAH NEGERI 1 KOTA GORONTALO
}

\author{
Mastin M. Gubali1 ${ }^{*}$, Yoseph Paramata ${ }^{2}$, Fitryane Lihawa ${ }^{3}$ \\ ${ }^{1}$ MTs Negeri Gorontalo, Jl. Poigar, Molosipat U, Kota Gorontalo, Goorntalo 96139 Indonesia \\ 2 Program Studi Pendidikan Fisika, Universitas Negeri Gorontalo,Jalan Jend. Sudirman No. 06 Kota \\ Gorontalo, Gorontalo, 96128 Indonesia \\ ${ }^{3}$ Program Studi Pendidikan Geografi, Universitas Negeri Gorontalo, Jalan Jend. Sudirman No. 06 Kota \\ Gorontalo, Gorontalo, 96128 Indonesia \\ Email: istinuskenat@gmail.com
}

Received: 04 February 2021. Accepted: 27 April 2021. Published: 30 April 2021

\section{ARTICLE INFO}

\section{Keywords:}

Integrated Science; Learning Tools; ADDIE's Model

How to cite:

Gubali, M.M, Paramata, J and Fitriyane, L. (2021). Pengembangan Perangkat Pembelajaran IPA Terpadu pada Materi Energi untuk Siswa Kelas VII Madrasah Tsanawiyah Negeri 1 Kota Gorontalo. Jambura Physics Journal. 3(1), 25-41.

DOI:

https://doi.org/10.34312 /jpj.v3i1.9861

\section{ABSTRACT}

The purpose and implementation of this research were to produce the development of class VII integrated science learning tools for students of MTsN. 1 Gorontalo's City dan to determine their effectiveness. The method in this research was used the Research and Development $(R \& D)$ approach. The step in the research was used the ADDIE models, where the development processes are: Analysis, Design, Development, Implementation, and Evaluation. The results were showed that interpretation of the average assessment of the learning tools (syllabus learning, RPP, LKPD, teaching materials, learning media, and learning outcomes test) was very appropriate. Where the validation index of all of the items was ranged from $0.75-0.95$. The conclusion was valid by calculating the consistency of the panelists' assessment, where the reliability was $0.77-0.95$. the results of observer's observation (1 and 2) on the implementation of learning as from using of learning tools in the average percentage was obtained $92,35 \%$. There was a significant increase in student outcomes at the pretest and posttest. This increase was included in the category (g-high). Thus the development of integrated science learning tools in energy materials for class VII students was meet requirements that were valid and reliable, feasible, and effective for improving student learning outcomes. 


\section{Pendahuluan}

Dalam mencapai tujuan pendidikan tersebut guru berperan penting dalam upaya peningkatan kualitas pendidikan yang berkaitan dengan tugas pokok dan fungsinya sebagai pendidik.Untuk menyelenggarakan pembelajaran aktif, kreatif, efektif dan menyenangkan, maka guru perlu merancang perencanaan pembelajaran, pemilihan model pembelajaran yang bervariasi, media yang menarik, dan alatevaluasi yang baik.Seorang guru dalammelaksanakan proses pembelajaran di kelas terlebih dahulu mempersiapkan model pembelajaran yang sesuai dengan perangkat pembelajaran yang tersedia. Melalui perangkat pembelajaran yang digunakan tergambar muatan yang akan diberikan kepada peserta didik, sehingga terjadi perubahan kompetensi peserta didik terhadap materi pembelajaran.

Keberhasilan seorang guru dalam pembelajaran sangatlah diharapkan, untuk memenuhi tujuan tersebut diperlukan suatu persiapan yang matang. Suparno (2002) mengemukakan sebelum guru mengajar (tahap persiapan) seorang guru diharapkan mempersiapkan bahan yang mau diajarkan, mempersiapkan alat-alat peraga/parktikum yang akan digunakan, mempersiapkan pertanyaan dan arahan untuk memancing siswa aktif belajar, mempelajari keadaan siswa, mengerti kelemahan dan kelebihan siswa, serta mempelajari pengetahuan awal siswa, kesemuanya ini akan terurai pelaksanaannya di dalam perangkat pembelajaran. Kurikulum adalah seperangkat rencana dan pengaturan mengenai tujuan, isi, dan bahan pelajaran serta cara yang digunakan sebagai pedoman penyelenggaraan kegiatan pembelajaran untuk mencapai tujuan pendidikan tertentu.

Bahan ajar merupakan salah satu bagian penting dalam proses pembelajaran. Sebagaimana Mulyasa (2006: 96) mengemukakan bahwa bahan ajar merupakan salah satu bagian dari sumber ajar yang dapat diartikan sesuatu yang mengandung pesan pembelajaran, baik yang bersifat khusus maupun yang bersifat umum yang dapat dimanfaatkan untuk kepentingan pembelajaran.

Dick et al., (2009) menambahkan bahwa instructional material contain the conten either written, mediated, or facilitated by an instructor that a student as use to achieve the objective also include information thet the learners will use to guide the progress. Berdasarkan ungkapan Dick, Carey, dan Carey dapat diketahui bahwa bahan ajar berisi konten yang perlu dipelajari oleh siswa baik berbentuk cetak atau yang difasilitasi oleh pengajar untuk mencapai tujuan tertentu.

Widodo dan Jasmadi dalam Lestari (2013: 1) menyatakan bahwa bahan ajar adalah seperangkat sarana atau alat pembelajaran yang berisikan materi pembelajaran, metode, batasan-batasan, dan cara mengevaluasi yang didesain secara sistematis dan menarik dalam rangka mencapai tujuan yang diharapkan, yaitu mencapai kompetensi dan subkompetensi dengan segala kompleksitasnya.

Pengertian ini menggambarkan bahwa bahan ajar hendaknya dirancang dan ditulis sesuai dengan kaidah pembelajaran, yakni disesuaikan materi pembelajaran, disusun berdasarkan atas kebutuhan pembelajaran, terdapat bahan evaluasi, serta bahan ajar tersebut menarik untuk dipelajari oleh siswa.

Wassid dan Sunendar (2011: 171) mengungkapkan bahwa bahan ajar merupakan seperangkat informasi yang harus diserap peserta didik melalui pembelajaran yang menyenangkan. Hal ini menunjukkan bahwa dalam penyusunan bahan ajar diharapkan siswa benar-benar merasakan manfaat bahan ajar atau materi 
Gubali, M.M. et al. / Jambura Physics Journal (2021) Vol. 3 (1): 24-41

itu setelah ia mempelajarinya. Wardhana (2010: 29) menambahkan bahwa bahan ajar merupakan suatu media untuk mencapai keinginan atau tujuan yang akan dicapai oleh peserta didik. Sedangkan menurut Opara dan Oguzor (2011: 66) mengungkapkan bahwa "instructional materials are the audio-visual materials (software/hardware) which can be used as alternative channels of communication in the teaching-learning process". Bahan ajar merupakan sumber belajar berupa visual maupun audiovisual yang dapat digunakan sebagai saluran alternatif pada komunikasi di dalam proses pembelajaran.

Berdasarkan kajian di atas, istilah bahan ajar yang digunakan dalam penelitian ini adalah suatu bahan/materi pelajaran yang disusun secara sistematis yang digunakan guru dan siswa dalam pembelajaran bahasa Indonesia di SMP untuk mencapai tujuan yang diharapkan.

Pengembangan perangkat desain pembelajaran terdapat beberapa model, salah satunya adalah model ADDIE. Model ADDIE ini muncul tahun 1990 yang dikembangkan oleh Reiser dan Mollenda. Menurut Benny A (2009:128-132) dikatakan model ADDIE ini dikarenakan 5 tahap yakni tahap analysis, design, development, implementation, evaluation.

Analisis merupakan tahap awal yang digunakan dalam desain pembelajaran.Tahap ini merupakan tahap yang menjelaskan mengenai hal-hal yang harus dipelajari oleh siswa. Analisis ini juga digunakan untuk mengklarifikasi apakah ada masalah yang akan dihadapi sehingga nantinya dapat menemukan solusi yang tepat untuk menghadapi masalah dalam penyelenggaraan program pembelajaran. Tahap analisis merupakan suatu proses mendefinisikan apa yang akan dipelajari oleh siswa yaitu menganalisis kebutuhan, mengidentifikasi masalah, merumuskan kompetensi yang dimilki siswa melalui analisis tugas serta menganalisis hasil yang dicapai (Muhammad, 2015: 24).

Desain pembelajaran juga dikatakan sebagai rnacangan dalam proses pembelajaran. Desain disusun dengan mempelajari masalah kemudian mencari solusi melalui identifikasi dari tahapan kebutuhan pada proses sebelumnya. Salah satu tujuan dari tahap ini adalah menentukan strategi pembelajaran yang tepat agar siswa dapat mencapai tujuan dari proses pendidikan, khususnya dalam mencapi standar kompetensi yang telah dietntukan dalam proses pembelajaran (Majid, 2011; 12).

Development

Pada tahap ini dimana desain yang sudah tersusun atau sudah terbuat kemudian ditindak lanjuti prosesnya melalui uji coba.Apakah desain yang dibuat tersebut layak untuk digunakan atau tidak. Jika memang desain yang sudah diuji cobakan tersebut berhasil atau dapat digunakan, maka desain harus dikembangkan agar lebih baik dan tentunya mendukung proses pembelajaran untuk mencapai tujuannya. Tahap pengembangan ini harus dipadukan dengan media yang kiranya dapat mendukung pembelajaran.

Implementation

Suatu rencana pembelajaran yang telah dibuat tidak akan diketahui hasilnya apabila tidak ada suatu tindakan yang dilakukan. Adanya tindakan tersebut sangat berarti karena pembelajaran akan memunculkan hal baru berupa dampak yang dapat dijadikan pengalaman atau bahkan acuan apabila telah membuahkan hasil, untuk itu perlu adanya implementasi yang berarti pelaksanaan dari suatu rencana dimana 
Gubali, M.M. et al. / Jambura Physics Journal (2021) Vol. 3 (1): 24-41

merupakan salah satu model ADDIE yang menjadi satu kesatuan dengan tahap-tahap sebelumnya sebagai penyempurnaan dalam pelaksanaan pembelajaran.

Tujuan utama dari tahap implementasi adalah: (1) Membimbing siswa untuk mencapai tujuan pembelajaran; (2) Menjamin adanya pemecahan masalah untuk mengatasi kesenjangan hasil belajar yang dihadapi siswa; dan (3) Memastikan bahwa pada akhirnya program pembelajaran siswa perlu memilki kompetensi.

\section{Evaluation}

Tahap evaluation merupakan tahap dimana tindakan dilakukan adalah untuk bertujuan mengetahui keberhasilan suatu rencana pembelajaran.Hal-hal yang digunakan guna suksesnya tahap ini tidak semata-mata utuh pada tahap ini saja namun evaluasi dapat terjadi pada tahap sebelumnya.Dalam tahap evaluasi memperhatikan tujuan yang hendak dicapai pada awal perencanaan.

\section{Metode}

\subsection{Jenis penelitian}

Penelitian ini merupakan penelitian pengembangan (Research and Development) yakni penelitian pengembangan perangkat pembelajaran IPA Terpadu. dengan prosedur penelitian mengacu pada model pengembangan yang digunakan yaitu model ADDIE yaitu menggunakan analisis statistik deskriptif dan analisis deskriptif kualitatif. Adapun perangkat pembelajaran yang dikembangkan mencakup; Silabus, Rencana Pelaksanaan Pembelajaran (RPP), Lembar Kerja Peserta Didik (LKPD), Bahan Ajar, Media Pembelajaran dan Tes Hasil Belajar.

\subsection{Desain penelitian}

Dalam penelitian ini, peneliti menggunakan model ADDIE dengan 5 tahapan pengembangan yakni :

Tahap analisis (Analyze)

Pada tahap analisis biasanya meliputi pelaksanaan analisis kebutuhan, identifikasi masalah dan merumuskan tujuan.Pada tahap analisis, pengembang mengidentifikasi kesenjangan antara kondisi pembelajar saat ini seperti pengetahuan, ketrampilan dan prilaku dengan hasil yang diinginkan. Selain itu juga penting untuk mempertimbangkan karakteristik pebelajar. Tujuan, pengalaman dan bagaimana hal ini dapat dimanfaatkan dalam proses pembelajaran. Pada tahap ini dilakukan analisis tujuan sesuai dengan kebutuhan yang dicapai.

Tahap analisis merupakan suatu proses yang akan mendefinisikan apa yang akan dipelajari pelajar maka untuk mengetahui atau menentukan apa yang harus dipelajari kita harus mengetahui beberapa kegiatan, diantaranya adalah melakukan analisis kebutuhan, mengidentifikasi masalah, melakukan analisis tugas oleh karena itu keluaran (output) yang akan dihasilkan adalah beberapa karakteristik pebelajar, identifikasi kesenjangan, identifikasi kebutuhan dan analisis tugas yang rinci berdasarkan kebutuhan.Tahap analisa terdiri dari 2 tahap, yaitu:1) analisis kerja (performance analysis) pengembangan menganalisis ketrampilan, pengetahuan dan motivasi belajar siswa pada proses pembelajaran, 2) analisis kebutuhan (need analysis), pada langkah ini pengembang menganalisis kebutuhan dan permasalahan belajar yaitu berupa materi yang relevan, web pembelajaran, media presentasi, pembelajaran, strategi pembelajaran, motivasi, kondisi belajar. 
Desain (Design)

Pada tahap desain terdiri dari perumusan tujuan umum yang dapat diukur, mengklasifikasikan pembelajar menjadi beberapa tipe, memilih aktifitas pembelajar dan memilih media. Pada tahap desain pengembang merencanakan tujuan belajar, proses penilaian, kegiatan pembelajaran dan isi pembelajaran. Tujuan biasanya di tetapkan untuk tiga domain, yaitu kognitif (berpikir), psikomotor (gerak) dan efektif (sikap) pertimbangan dalam proses ini meliputi kegiatan memilih media dan strategi pembelajaran yang akan digunakan dalam proses pembelajaran berbasis penggabungan (blended).

Pada tahap ini yaitu mendesain bahan ajar sedemikian rupa dengan merumuskan tujuan pembelajaran baik umum maupun khusus selanjutnya mengembangkan butir-butir tes atau soal untuk mengukur tingkat kemajuan siswa dan tingkat pencapaian tujuan yang telah dirumuskan, dan yang terakhir mengembangkan strategi pembelajaran. Pengembangan pembelajaran berbasis penggabungan (blended) ini juga didesain dengan memperhatikan prinsip-prinsip desain pesan agar dapat menarik perhatian siswa.

Pada proses ini pengembang merekayasa model perangkat pembelajaran IPA Terpadu sedemikian rupa dengan merumuskan tujuan pembelajaran baik umum maupun khusus. Selanjutnya mengembangkan butir-butir tes atau soal yang digunakan untuk mengukur tingkat kemajuan siswa dan tingkat pencapaian tujuan yang telah dirumuskan. Dan terakhir mengembangkan strategi pembelajaran. Pengembangan perangkat pembelajaran IPA Terpadu juga didesain untuk memperhatikan prinsip-prinsip desain pesan agar dapat menarik perhatian siswa.

Pengembangan (Development)

Tahap pengembangan meliputi menyiapkan material untuk pebelajar dan pengajar sesuai dengan spesifikasi produk yang dikembangkan. Paa tahap pengembangan. yaitu mengembangkan produk sesuai dengan materi dan tujuan yang akan disampaikan dalam pembelajaran, begitu pula dengan lingkungan belajar lain yang akan mendukung proses pembelajaran, semuanya harus disiapkan dalam tahap ini.

Pengembangan berupaya menyusun dan merekayasa media pembelajaran berdasarkan informasi yang telah diperoleh dari berbagai tahap sebelumnya. Pengembang memodifikasi media yang telah ada berupa media pembelajaran, media presentasi, panduan operasional siswa dan tenaga pendidik, serta menentukan media dan strategi siswa yang disesuaikan dengan karakteristik siswa dalam perangkat pembelajaran IPA Terpadu.

\section{Implementasi (Implementation)}

Tahap implementasi meliputi pengiriman atau penggunaan produk pengembangan untuk diaplikasikan dalam proses pembelajaran yang sudah didesain sedemikian rupa pada tahap desain. Pada tahap ini dimulai dengan menyiapkan pelatihan instruktur atau pengajar, serta menyiapkan peralatan belajar dan lingkungan yang dikondisikan setelah semuanya tersedia maka desainer bisa mengimplementasikan produk yang dikembangkan kedalam proses pembelajaran.

Pada langkah ini model pembelajaran IPA Terpadu divalidasi terlebih dahulu kepada para ahli, yakni ahli isi dan ahli desain. Setelah dilakukan validasi dan 
Gubali, M.M. et al. / Jambura Physics Journal (2021) Vol. 3 (1): 24-41

dinyatakan layak maka uji coba akan dilakukan pada uji coba perorangan kelompok kecil dan lapangan yaitu peserta didik MTs Negeri 1 Kota Gorontalo dalam uji lapangan ini selain menggunakan angket sebagai pengumpul data, pengembang juga mengadakan proses pembelajaran dengan menggunakan media yang sudah dikembangkan.

\section{Evaluasi (Evaluation)}

Pada tahap evaluasi meliputi 2 bentuk evaluasi yaitu pretest dan postest,kemudian dilakukan revisi apabila diperlukan. Evaluasi yang dilakukan pada penelitian pengembangan kali ini yaitu evaluasi formatif pada tiap fase pengembangan yaitu selanjutnya dilakukan revisi untuk mengetahui apakah produk pengembangan apakah sudah valid untuk diaplikasikan dalam pembelajaran. Pada tahap evaluasi desainer melakukan evaluasi terhadap produk pengembangan yang meliputi isi / materi, media pembelajaran yang dikembangkan.

\subsection{Instrumen penelitian}

Instrumen pengumpulan data pada penelitian ini adalah lembar validasi perangkat pembelajaran berdasarkan penilaian para ahli.

\subsection{Teknik analisis data}

Analisa data, digunakan untuk mengetahui kualitas perangkat pembelajaran yang dikembangkan. Data yang diperoleh dalam penelitian ini adalah data hasil validasi produk pengembangan oleh para ahli pembelajaran IPA.

Untuk data kuantitatif, supaya dapat dibaca dalam bentuk informasi yang terstruktur maka analisis datanya menggunakan presentase nilai pada masingmasing pengukuran.

Tabel 1. Interpretasi hasil analisis untuk masing-masing instrumen

\begin{tabular}{ll}
\hline Tingkat Pencapaian & Kualifikasi \\
\hline $87,5 \%-100 \%$ & Sangat Baik (SB) \\
$62,5 \%-87,49 \%$ & Baik (B) \\
$37,7 \%-62,49 \%$ & Cukup Baik (CB) \\
$12,50 \%-37,49 \%$ & Kurang Baik (KB) \\
$0 \%-12.49 \%$ & Tidak Baik (TB) \\
\hline
\end{tabular}

Untuk mengetahui tentang efektifitas hasil produk pengembangan pembelajaran pembelajaran IPA Terpadu, maka digunakan tekhnik analisis diskriptif untuk mengolah data berdasarkan instrumen pengumpulan data, data kuantitatif dari instrumen penelitian ini dianalisis menggunakan presentasi nilai pada masingmasing pengukuran dengan rumus pada penjelasan diatas.

Selain itu untuk mengetahui tingkat keefektifan instrument maka dilakukan uji validitas instrument. Pada setiap validasi komponen instrumen penilaian validator memberikan penilaian. Masing-masing komponen dilengkapi skor pilihan 1-5 dan saran perbaikan. Setelah dilakukan validasi oleh para ahli, hasil validasi tersebut dianalisis dengan memperhatikan rerata penilaian panelis/validator dan indeks validitas isi (Aiken dalam Rohani, 2013: 47) sebagai berikut: 


$$
\mathrm{V}=\frac{\sum \mathrm{n}_{\mathrm{i}}\left|\mathrm{i}-\mathrm{i}_{0}\right|}{\mathrm{N}(\mathrm{C}-1)}
$$

Keterangan:

$V \quad=$ Validitas isi

$n_{i}=$ Jumlah panelis/validatator yang memilih $\mathrm{i}$

$i=$ skor pilihan setiap butir instrumen, dimana $\mathrm{i}=1,2,3,4,5$

$N=$ Jumlah Panelis/validator

$C=$ banyaknya skor pilihan panelis yaitu ada 5

$i_{0} \quad=$ skor paling rendah yaitu 1

Skala penilaian validitas isi dikembangkan dari metode "quantification of Content Validity, yaitu 1 (tidak sesuai), 2 (kurang sesuai), 3 (cukup sesuai), 4 (sesuai), 5 (sangat sesuai) (Gregori dalam Rohani, 2013: 48), mengacu pada pendapat Gregory tersebut, maka interpretasi isi dapat disajikan seperti tabel 2 berikut ini.

Tabel 2. Skala Penilaian Validitas Isi

\begin{tabular}{ll}
\hline Rentang Nilai & Interpretasi \\
\hline $0,81-1,00$ & Sangat Valid \\
$0,61-0,80$ & Valid \\
$0,41-0,60$ & Cukup Valid \\
$0,21-0,40$ & Tidak Valid \\
$0,00-0,20$ & Sangat Tidak Valid \\
\hline
\end{tabular}

Kriteria suatu butir atau aspek dikatakan memenuhi validitas isi (Valid) didasarkan pada skala penilaian panelis dengan kategori sesuai dan sangat sesuai, yang berarti memiliki rentang nilai 0,61 - 0,80 dan 0,81 - 1,00. Selajutnya untuk menghitung reliabilitas kekonsistenan panelis (Guilford dalam Rohani, 2013: 48) yaitu sebagai berikut :

$\mathrm{r}_{\mathrm{kk}}=\frac{\mathrm{v}_{\mathrm{p}}-\mathrm{v}_{\mathrm{e}}}{\mathrm{v}_{\mathrm{p}}}$

Keterangan:

$r_{k k} \quad=$ reliabilitas kekonsistenan panelis

$V_{p} \quad=$ varian butir, diperoleh dari jumlah kuadrat butir $\mathrm{Jk}_{\text {butir- }} \mathrm{db}$,

$d_{b} \quad=\mathrm{n}-1$ ( $\mathrm{n}=$ jumlah butir)

$V_{e} \quad=$ varian sisa, yang diperoleh dari jumlah kuadrat sisa $\mathrm{Jk}_{\mathrm{sisa}}-\mathrm{d}_{\mathrm{b}}$,

$d_{b \text { Sisa }}=\mathrm{db}$ butir $\times \mathrm{db}_{\text {panelis }}$

Selain itu, data hasil pengamatan pelaksanaan pembelajaran dari observer dapat dianalisis dengan menggunakan rumus:

$$
\text { Nilai }=\frac{\text { Jumlah Skor yang Diperoleh }}{\text { Skor Maksimum }} \quad \times 100 \%
$$

Interpretasi keterlaksanaan kegiatan sebagai berikut:
$86 \%-100 \%$
: Sangat Baik
$76 \%-85 \%$
: Baik
$66 \%-75 \%$
: Cukup
$56 \%-65 \%$
: Kurang
$0 \%-55 \%$
: Sangat Kurang 
Gubali, M.M. et al. / Jambura Physics Journal (2021) Vol. 3 (1): 24-41

\section{Hasil dan Pembahasan}

Adapun hasil Perangkat pembelajaran dalam penelitian pengembangan ini berupa saran atau masukan untuk revisi Perangkat dan juga skor penilaian dari para ahli sebagai berikut:

\section{Silabus}

Silabus yang divalidasi oleh para ahli dikembangkan berdasarkan 9 komponen atau indikator yakni, Identitas Silabus, Kompetensi inti, Kompetensi dasar, Indikator Pembelajaran, Materi pokok, Kegiatan pembelajaran, Penilaian, Alokasi waktu, dan Sumber belajar.

Adapun revisi silabus berdasarkan masukan para ahli dapat dilihat pada tabel 3 berikut ini:

Tabel 3. Revisi Silabus Berdasarkan Masukan Para Ahli

\begin{tabular}{|c|c|c|c|}
\hline No & Bagian yang direvisi & Sebelum direvisi & Sesudah direvisi \\
\hline 1 & $\begin{array}{l}\text { Kompetensi Dasar } \\
\text { (KD) }\end{array}$ & $\begin{array}{l}\text { KD untuk KI -1 dan KI - } \\
2 \text { dimasukan dalam } \\
\text { format }\end{array}$ & $\begin{array}{l}\text { KD disesuaikan } \\
\text { langsung dengan } \\
\text { materi pokok atau } \\
\text { topik yang dibahas, } \\
\text { yakni KD untuk KI - } 3 \\
\text { dan KI - } 4\end{array}$ \\
\hline 2. & Kegiatan & Dirincikan uraian & Telah diuraikan \\
\hline & Pembelajaran & $\begin{array}{l}\text { kegiatan guru dan siswa } \\
\text { secara singkat }\end{array}$ & $\begin{array}{l}\text { kegiatan guru dan } \\
\text { siswa secara singkat }\end{array}$ \\
\hline
\end{tabular}

Hasil penilaian dari 5 orang panelis terhadap silabus nampak dalam tabel 4 berikut :

Tabel 4. Hasil Penilaian Panelis terhadap Silabus

\begin{tabular}{|c|c|c|c|c|c|c|c|c|c|c|}
\hline \multirow{2}{*}{$\begin{array}{l}\text { No. } \\
\text { Butir }\end{array}$} & \multicolumn{5}{|c|}{ Panelis } & \multirow{2}{*}{ Jumlah } & \multirow{2}{*}{ Rerata } & \multirow{2}{*}{ Jumlah-k } & \multirow{2}{*}{ Validitas } & \multirow{2}{*}{ Ket } \\
\hline & 1 & 2 & 3 & 4 & 5 & & & & & \\
\hline 1 & 5 & 5 & 5 & 3 & 4 & 22 & 4.4 & 17 & 0.85 & Valid \\
\hline 2 & 5 & 4 & 5 & 3 & 4 & 21 & 4.2 & 16 & 0.8 & Valid \\
\hline 3 & 5 & 5 & 4 & 4 & 3 & 21 & 4.2 & 16 & 0.8 & Valid \\
\hline 4 & 5 & 5 & 4 & 5 & 3 & 22 & 4.4 & 17 & 0.85 & Valid \\
\hline 5 & 5 & 4 & 5 & 5 & 4 & 23 & 4.6 & 18 & 0.9 & Valid \\
\hline 6 & 5 & 4 & 4 & 4 & 5 & 22 & 4.4 & 17 & 0.85 & Valid \\
\hline 7 & 5 & 5 & 4 & 4 & 4 & 22 & 4.4 & 17 & 0.85 & Valid \\
\hline 8 & 5 & 4 & 3 & 4 & 5 & 21 & 4.2 & 16 & 0.8 & Valid \\
\hline 9 & 5 & 5 & 4 & 3 & 4 & 21 & 4.2 & 16 & 0.8 & Valid \\
\hline
\end{tabular}

Hasil perhitungan penilaian validator terhadap butir/komponen silabus, menunjukkan bahwa dari 5 orang validator rata-rata memberikan penilaian terhadap silabus diperoleh bahwa rentang nilai rata-rata berada pada 4,20 - 4,60. Dengan konstanta validitas berada pada koefisien 0,8 hingga 0,9. Angka ini tentunya 
Gubali, M.M. et al. / Jambura Physics Journal (2021) Vol. 3 (1): 24-41

menunjukan tingkat validitas tinggi yang secara langsung menyepakati bahwa silabus yang digunakan cukup valid untuk di pakai. Analisis uji reliabilitas instrument dapat dilihat dalam lampiran.

Hasil analisis validitas isi setiap butir yang dihitung dengan menggunakan rumus Aiken, dengan jumlah panelis / validator sebanyak 5 orang dan banyaknya skor pilihan penilaian pada setiap butir adalah 5 yang dimulai dari 1 (skor terendah) sampai 5 (skor tertinggi). Hasil analisis ini kemudian diperkuat dengan hasil perhitungan kekonsistenan penilaian panelis yang diperoleh dari koefisien reabilitas yaitu sebesar 0,99.

$R P P$

RPP divalidasi oleh para ahli dikembangkan berdasarkan 11 komponen atau indikator, yakni ; (1) mencantumkan identitas RPP, (2) mencantumkan kompetensi inti ( KI ), (3) mencantumkan kompetensi dasar (KD), (4) memiliki indikator, (5) mencantumkan tujuan pembelajaran, (6) memiliki materi pembelajaran, (7) mencantumkan pendekatan/model/metode pembelajaran, (8) mencantumkan alat/media pembelajaran, (9) mencantumkan sumber belajar, (10) mencantumkan langkah-langkah pembelajaran , (11) memiliki penilaian hasil belajar. berikut

Adapun revisi RPP berdasarkan masukan para ahli dapat dilihat pada tabel 5

Tabel 5. Revisi RPP Berdasarkan Masukan Para Ahli.

\begin{tabular}{clll}
\hline No & Bagian yang direvisi & Sebelum direvisi & Sesudah direvisi \\
\hline 1 & $\begin{array}{l}\text { Langkah-langkah } \\
\text { pembelajaran }\end{array}$ & $\begin{array}{l}\text { Langkah pembelajaran } \\
\text { terlalu umum }\end{array}$ & $\begin{array}{l}\text { Sudah diperbaiki dengan } \\
\text { langkah-langkah yang } \\
\text { detail }\end{array}$ \\
2 & Pembuka RPP & Identitasnya belum jelas & $\begin{array}{l}\text { Diperbaiki dengan } \\
\text { rincian identitas RPP }\end{array}$ \\
3 & Format Penilaian sikap & $\begin{array}{l}\text { Penilaian afektif kurang } \\
\text { terukur. }\end{array}$ & $\begin{array}{l}\text { Penilaian afektif } \\
\text { diperjelas }\end{array}$ \\
\hline
\end{tabular}
berikut:

Hasil penilaian dari 5 orang panelis terhadap RRP dapat dilihat pada tabel 6

Tabel 6. Hasil Penilaian Panelis terhadap RPP

\begin{tabular}{|c|c|c|c|c|c|c|c|c|c|c|}
\hline \multirow{2}{*}{$\begin{array}{l}\text { No. } \\
\text { Butir }\end{array}$} & \multicolumn{5}{|c|}{ Panelis } & \multirow{2}{*}{ Jumlah } & \multirow{2}{*}{ Rerata } & \multirow{2}{*}{ Juml-k } & \multirow{2}{*}{ Validitas } & \multirow{2}{*}{ Ket } \\
\hline & 1 & 2 & 3 & 4 & 5 & & & & & \\
\hline 1 & 5 & 5 & 5 & 4 & 5 & 24 & 4.8 & 19 & 0.95 & Valid \\
\hline 2 & 5 & 4 & 4 & 5 & 5 & 23 & 4.6 & 18 & 0.9 & Valid \\
\hline 3 & 5 & 5 & 4 & 4 & 3 & 21 & 4.2 & 16 & 0.8 & Valid \\
\hline 4 & 5 & 4 & 5 & 3 & 3 & 20 & 4 & 15 & 0.75 & Valid \\
\hline 5 & 5 & 5 & 4 & 4 & 4 & 22 & 4.4 & 17 & 0.85 & Valid \\
\hline 6 & 5 & 5 & 5 & 4 & 5 & 24 & 4.8 & 19 & 0.95 & Valid \\
\hline 7 & 5 & 3 & 5 & 5 & 4 & 22 & 4.4 & 17 & 0.85 & Valid \\
\hline 8 & 5 & 4 & 4 & 3 & 5 & 21 & 4.2 & 16 & 0.8 & Valid \\
\hline
\end{tabular}


Gubali, M.M. et al. / Jambura Physics Journal (2021) Vol. 3 (1): 24-41

\begin{tabular}{|c|c|c|c|c|c|c|c|c|c|c|}
\hline \multirow{2}{*}{$\begin{array}{l}\text { No. } \\
\text { Butir }\end{array}$} & \multicolumn{5}{|c|}{ Panelis } & \multirow{2}{*}{ Jumlah } & \multirow{2}{*}{ Rerata } & \multirow{2}{*}{ Juml-k } & \multirow{2}{*}{ Validitas } & \multirow{2}{*}{ Ket } \\
\hline & 1 & 2 & 3 & 4 & 5 & & & & & \\
\hline 9 & 5 & 5 & 3 & 5 & 4 & 22 & 4.4 & 17 & 0.85 & Valid \\
\hline 10 & 5 & 4 & 4 & 3 & 5 & 21 & 4.2 & 16 & 0.8 & Valid \\
\hline 11 & 5 & 4 & 5 & 4 & 4 & 22 & 4.4 & 17 & 0.85 & Valid \\
\hline
\end{tabular}

Hasil perhitungan penilaian validator terhadap butir/komponen RRP, menunjukkan bahwa dari 5 orang validator rata-rata memberikan penilaian terhadap RPP diperoleh bahwa butir 1,2,5,6,7, 9 dan 10 diinterpretasikan "sangat sesuai" dengan rentang nilai berada pada 4,40 - 4,80. Kemudian butir 3, 4 dan 8 diinterpretasikan "sesuai" dengan rerata nilai 4,00 - 4,20.

Hasil analisis validitas isi setiap butir yang dihitung dengan menggunakan rumus Aiken, dengan jumlah panelis / validator sebanyak 5 orang dan banyaknya skor pilihan penilaian pada setiap butir adalah 5 yang dimulai dari 1 (skor terendah) sampai 5 (skor tertinggi), diperoleh bahwa indeks validasi semua butir antara 0,75 0,95 dengan kesimpulan "Valid".

Hasil analisis ini kemudian diperkuat dengan hasil perhitungan kekonsistenan penilaian panelis yang diperoleh dari koefisien reabilitas yaitu sebesar 0,99.

$L K P D$

LKPD divalidasi oleh para ahli dikembangkan berdasarkan 15 indikator, yakni; (1) judul dan tujuan percobaan sesuai dengan materi pembelajaran (2) percobaan dikembangkan menggunakan pendekatan saintifik (mengamati, menanya, mencoba, mengasosiasikan, mengkomunikasikan), (3) percobaan mudah dilakukan dan tidak membutuhkan waktu yang lama (4) percobaan dilakukan untuk menyelidiki atau membuktikan suatu teori, (5) terdapat pertanyaan pendukung analisis data, (6) terdapat judul percobaan, (7) terdapat tujuan percobaan (8) Pemilihan Alat dan bahan, (9) memiliki prosedur kerja/langkah-langkah percobaan (10) jika terdapat gambar /grafik /tabel / diagram, harus jelas dan berfungsi, (11) rumusan kalimat dalam LKPD mudah dipahami peserta didik, (12) menggunakan bahasa Indonesia yang baku. (13) tidak menggunakan kata-kata/kalimat yang menimbulkan penafsiran ganda atau salah pengertian, (14) tidak mengandung kata yang dapat menyinggung perasaan, (15) tidak menggunakan bahasa yang berlaku setempat/tabu.

Adapun revisi LKPD berdasarkan masukan para ahli dapat dilihat pada tabel 7 berikut:

Tabel 7. Revisi LKPD Berdasarkan Masukan Para Ahli

\begin{tabular}{clll}
\hline No & Bagian yang direvisi & Sebelum direvisi & Sesudah direvisi \\
\hline 1 & Judul LKPD & Tulisan Judul LKPD & Ditambahkan judul \\
& & $\begin{array}{l}\text { disertakan dengan materi } \\
\text { ajar. }\end{array}$ & materi ajar dalam setiap \\
& & & \\
\hline
\end{tabular}

Hasil penilaian dari 5 orang panelis terhadap LKPD dapat dilihat pada tabel 8 berikut: 
Gubali, M.M. et al. / Jambura Physics Journal (2021) Vol. 3 (1): 24-41

\begin{tabular}{|c|c|c|c|c|c|c|c|c|c|c|}
\hline \multirow{2}{*}{$\begin{array}{l}\text { No. } \\
\text { Butir }\end{array}$} & \multicolumn{5}{|c|}{ Panelis } & \multirow{2}{*}{ Jumlah } & \multirow{2}{*}{ Rerata } & \multirow{2}{*}{ Jml-k } & \multirow{2}{*}{ Validitas } & \multirow{2}{*}{ Ket } \\
\hline & 1 & 2 & 3 & 4 & 5 & & & & & \\
\hline \multicolumn{11}{|l|}{ Materi } \\
\hline 1 & 5 & 5 & 5 & 4 & 5 & 24 & 4.8 & 19 & 0.95 & Valid \\
\hline 2 & 5 & 4 & 4 & 5 & 5 & 23 & 4.6 & 18 & 0.9 & Valid \\
\hline 3 & 5 & 5 & 4 & 4 & 3 & 21 & 4.2 & 16 & 0.8 & Valid \\
\hline 4 & 5 & 4 & 5 & 3 & 3 & 20 & 4 & 15 & 0.75 & Valid \\
\hline 5 & 5 & 5 & 4 & 4 & 4 & 22 & 4.4 & 17 & 0.85 & Valid \\
\hline \multicolumn{11}{|c|}{ Konstruksi } \\
\hline 6 & 5 & 5 & 5 & 4 & 5 & 24 & 4.8 & 19 & 0.95 & Valid \\
\hline 7 & 5 & 3 & 5 & 5 & 4 & 22 & 4.4 & 17 & 0.85 & Valid \\
\hline 8 & 5 & 4 & 4 & 3 & 5 & 21 & 4.2 & 16 & 0.8 & Valid \\
\hline 9 & 5 & 5 & 3 & 5 & 4 & 22 & 4.4 & 17 & 0.85 & Valid \\
\hline 10 & 4 & 5 & 3 & 5 & 4 & 21 & 4.2 & 16 & 0.8 & Valid \\
\hline \multicolumn{11}{|l|}{ Bahasa } \\
\hline 11 & 4 & 5 & 3 & 4 & 5 & 21 & 4.2 & 16 & 0.8 & Valid \\
\hline 12 & 3 & 5 & 4 & 5 & 3 & 20 & 4 & 15 & 0.75 & Valid \\
\hline 13 & 4 & 4 & 5 & 3 & 5 & 21 & 4.2 & 16 & 0.8 & Valid \\
\hline 14 & 5 & 3 & 5 & 4 & 5 & 22 & 4.4 & 17 & 0.85 & Valid \\
\hline 15 & 5 & 4 & 5 & 4 & 4 & 22 & 4.4. & 17 & 0.85 & Valid \\
\hline
\end{tabular}

Hasil perhitungan penilaian validator terhadap butir/komponen LKPD, menunjukkan bahwa dari 5 orang validator memberikan penilaian terhadap LKPD diperoleh butir 1,2,3,5,6,7,9,10, 11,13,14 dan 15 diiinterpretasikan "sangat sesuai" dengan rentang nilai berada pada 4,20 - 4,80. Kemudian butir 4,8 dan 12 diinterpretasikan "sesuai" dengan rerata nilai 4,00.

Hasil analisis validitas isi setiap butir yang dihitung dengan menggunakan rumus Aiken, diperoleh bahwa indeks validasi semua butir antara 0,75 - 0,95 dengan kesimpulan "Valid". Hasil analisis ini kemudian diperkuat dengan hasil perhitungan kekonsistenan penilaian panelis yang diperoleh dari koefisien reabilitas yaitu sebesar 0,77 .

\section{Bahan ajar}

Bahan Ajar yang divalidasi oleh para ahli dikembangkan berdasarkan 4 komponen atau indikator, yakni; (1) Isi, (2) Keterbacaan, (3) Bahasa, (4) Perwajahan/ Penampilan. tabel 9 .

Adapun revisi bahan ajar berdasarkan masukan para ahli dapat dilihat pada 
Gubali, M.M. et al. / Jambura Physics Journal (2021) Vol. 3 (1): 24-41

Tabel 9. Revisi Bahan Ajar Berdasarkan Masukan Para Ahli.

\begin{tabular}{llll}
\hline No & $\begin{array}{l}\text { Bagian yang } \\
\text { direvisi }\end{array}$ & Sebelum direvisi & Sesudah direvisi \\
\hline 1. & Isi & $\begin{array}{l}\text { Uraian materi dalam } \\
\text { bahan ajar kurang fokus }\end{array}$ & $\begin{array}{l}\text { Sudah diperbaiki' } \\
\text { dengan rincian dan fokus } \\
\text { materi }\end{array}$ \\
& Keterangan gambar dan & $\begin{array}{l}\text { Keterangan gambar } \\
\text { tabel belum ada. }\end{array}$ & $\begin{array}{l}\text { sudah dimasukan } \\
\text { Diperbaiki dengan } \\
\text { bahasa yang sederhana } \\
\end{array}$ \\
& $\begin{array}{l}\text { Kurang merangsang } \\
\text { kemampuan berpikir } \\
\text { anak }\end{array}$ & $\begin{array}{l}\text { kasus dalam kehidupan } \\
\text { sehari-hari }\end{array}$ \\
\hline
\end{tabular}

Hasil penilaian dari 5 orang panelis terhadap Bahan Ajar dapat dilihat pada tabel 10 berikut.

Tabel 10. Hasil Penilaian Panelis terhadap Bahan Ajar

\begin{tabular}{ccccccccccc}
\hline \multirow{2}{*}{$\begin{array}{c}\text { No. } \\
\text { Butir }\end{array}$} & \multicolumn{4}{c}{ Panelis } & & & & & & \\
\cline { 2 - 6 } & 1 & 2 & 4 & 5 & & Jumlah & Rerata & Jml-k & Validitas & Ket \\
\hline 1 & 5 & 5 & 5 & 4 & 4 & 23 & 4.6 & 18 & 0.9 & Valid \\
2 & 4 & 5 & 5 & 3 & 4 & 21 & 4.2 & 16 & 0.8 & Valid \\
3 & 3 & 4 & 5 & 4 & 5 & 21 & 4.2 & 16 & 0.8 & Valid \\
4 & 5 & 5 & 3 & 5 & 4 & 22 & 4.4 & 17 & 0.85 & Valid \\
\hline
\end{tabular}

Hasil perhitungan penilaian validator terhadap butir/komponen Bahan Ajar, menunjukkan bahwa dari 5 orang validator memberikan penilaian terhadap Bahan Ajar diperoleh butir 1, dan 4 diiinterpretasikan "sangat sesuai" dengan rentang nilai 4,40 dan 4.60. Kemudian butir 2dan 3, diinterpretasikan "sesuai" dengan rerata nilai 4.30 .

Hasil analisis validitas isi setiap butir yang dihitung dengan menggunakan rumus Aiken, diperoleh bahwa indeks validasi semua butir antara 0,80 - 0,90 dengan kesimpulan "Valid".

Hasil analisis ini kemudian diperkuat dengan hasil perhitungan kekonsistenan penilaian panelis yang diperoleh dari koefisien reabilitas yaitu sebesar 0,99.

Media pembelajaran

Media Pembelajaran yang divalidasi oleh para ahli dikembangkan berdasarkan 8 komponen atau indikator, yakni; (1) Media pembelajaran sesuai dengan materi (2), Media sesuai dengan tujuan pembelajaran (3) Mendukung isi bahan pembelajaran, (4) Menarik perhatian siswa (5) Bermakna, (6) Mudah dipahami siswa, (7) Sesuai dengan taraf berpikir siswa, (8) Menimbulkan gairah belajar

Adapun revisi media pembelajaran berdasarkan masukan para ahli dapat dilihat pada tabel 11 berikut. 
Gubali, M.M. et al. / Jambura Physics Journal (2021) Vol. 3 (1): 24-41

\begin{tabular}{|c|c|c|c|c|}
\hline No & $\begin{array}{l}\text { Bagian } \\
\text { direvisi }\end{array}$ & yang & Sebelum direvisi & Sesudah direvisi \\
\hline 1 & $\begin{array}{l}\text { Lembaran } \\
\text { Slide }\end{array}$ & setiap & $\begin{array}{l}\text { Lembaran slide yang ditampilkan } \\
\text { tidak diberi nomor urut atau } \\
\text { pertemuan berdasarkan RPP }\end{array}$ & $\begin{array}{lr}\text { Sudah } & \text { diperbaiki } \\
\text { dengan } & \text { memberi } \\
\text { nomor urut pada } \\
\text { slide } & \text { berdasarkan } \\
\text { pertemuan pada RPP. }\end{array}$ \\
\hline 2 & $\begin{array}{l}\text { Tampilan } \\
\text { gambar }\end{array}$ & & $\begin{array}{l}\text { Tulisan pada gambar dibuat lebih } \\
\text { besar }\end{array}$ & $\begin{array}{lr}\text { Sudah diperbaiki, } \\
\text { sehingga } & \text { tulisan } \\
\text { dapat dibaca } & \end{array}$ \\
\hline
\end{tabular}

Hasil penilaian dari 5 orang panelis terhadap Media Pembelajaran dapat dilihat pada tabel 12 berikut.

Tabel 12. Penilaian Panelis terhadap Media Pembelajaran

\begin{tabular}{|c|c|c|c|c|c|c|c|c|c|c|}
\hline \multirow{2}{*}{ No. Butir } & \multicolumn{5}{|c|}{ Panelis } & \multirow{2}{*}{ Jumlah } & \multirow{2}{*}{ Rerata } & \multirow{2}{*}{ Jml-k } & \multirow{2}{*}{ Validitas } & \multirow{2}{*}{ Ket } \\
\hline & 1 & 2 & 3 & 4 & 5 & & & & & \\
\hline 1 & 5 & 4 & 4 & 5 & 5 & 23 & 4.6 & 18 & 0.9 & Valid \\
\hline 2 & 4 & 5 & 5 & 4 & 4 & 22 & 4.4 & 17 & 0.85 & Valid \\
\hline 3 & 5 & 4 & 3 & 4 & 5 & 21 & 4.2 & 16 & 0.8 & Valid \\
\hline 4 & 5 & 4 & 3 & 5 & 4 & 21 & 4.2 & 16 & 0.8 & Valid \\
\hline 5 & 5 & 4 & 5 & 4 & 5 & 23 & 4.6 & 18 & 0.9 & Valid \\
\hline 6 & 4 & 3 & 5 & 5 & 3 & 20 & 4 & 15 & 0.75 & Valid \\
\hline 7 & 5 & 4 & 4 & 5 & 3 & 21 & 4.2 & 16 & 0.8 & Valid \\
\hline 8 & 5 & 3 & 5 & 5 & 4 & 22 & 4.4 & 17 & 0.85 & Valid \\
\hline
\end{tabular}

Hasil perhitungan penilaian validator terhadap butir/komponen Media Pembelajaran, menunjukkan bahwa dari 5 orang validator memberikan penilaian terhadap Media Pembelajaran diperoleh butir 1,2,3,4,57, dan 8 diiinterpretasikan "sangat sesuai" dengan rentang nilai 4,20-4,60. Kemudian butir 6 diinterpretasikan "sesuai" dengan rerata nilai 4,00.

Hasil analisis validitas isi setiap butir yang dihitung dengan menggunakan rumus Aiken, diperoleh bahwa indeks validasi semua butir antara 0,75 - 0,9 dengan kesimpulan "Valid".

Hasil analisis ini kemudian diperkuat dengan hasil perhitungan kekonsistenan penilaian panelis yang diperoleh dari koefisien reabilitas yaitu sebesar 0,99.

Tes Hasil Belajar

Tes hasil belajar yang divalidasi oleh para ahli dikembangkan berdasarkan 15 komponen atau indikator, yakni; (1) Soal sesuai dengan indikator, (2) Batasan pertanyaan dan jawaban yang diharapkan sesuai, (3) Materi yang diukur sesuai dengan kompetensi (urgensi, relevansi, kontinuitas, keterpakaian ), (4) Isi materi yang ditanyakan sesuai dengan petunjuk pengukuran jenjang, jenis sekolah dan tingkat kelas, (5) Memiliki tingkatan kognitif, (6) Ada identitas soal, (7) Ada petunjuk yang 
Gubali, M.M. et al. / Jambura Physics Journal (2021) Vol. 3 (1): 24-41

jelas mengenai cara mengerjakan soal, (8) Rumusan kalimat soal menggunakan kata tanya yang menuntut satu jawaban yang tepat, (9) Gambar/grafik/tabel/diagram dan sebagainya, jelas dan berfungsi, (10) Ada pedoman penskoran, (11) Rumusan kalimat soal komutati, (12) Butir soal menggunakan bahasa Indonesia yang baku, (13) Tidak menggunakan kata-kata/kalimat yang menimbulkan penafsiran ganda atau salah pengertian, (14) Tidak mengandung kata yang dapat menyinggung perasaan, (15) Tidak menggunakan bahasa yang berlaku setempat/tabu.

Adapun revisi Tes Hasil Belajar berdasarkan masukan para ahli dapat dilihat pada tabel 13 berikut.

Tabel 13. Revisi Tes Hasil Belajar Berdasarkan Masukan Para Ahli

\begin{tabular}{clll}
\hline No & Bagian yang direvisi & Sebelum direvisi & Sesudah direvisi \\
\hline 1 & Kisi - kisi soal & $\begin{array}{l}\text { Format kisi-kisi hanya harus } \\
\text { mencakup semua tingkatan } \\
\text { pengetahuan }\end{array}$ & $\begin{array}{l}\text { Kembali dimasukan kisi- } \\
\text { kisi yang memuat C1-C6 }\end{array}$ \\
2 & Butir Soal & $\begin{array}{l}\text { Kunci jawaban harus ada } \\
\text { langkah-langkahnya }\end{array}$ & $\begin{array}{l}\text { Kunci jawaban } \\
\text { disertakan dengan } \\
\text { tahapannya }\end{array}$ \\
\hline
\end{tabular}

Hasil penilaian dari 5 orang panelis dapat dilihat pada tabel 14 berikut.

Tabel 14. Penilaian Panelis terhadap Instrumen Tes Hasil Belajar

\begin{tabular}{|c|c|c|c|c|c|c|c|c|c|c|}
\hline \multirow{2}{*}{$\begin{array}{l}\text { No. } \\
\text { Butir }\end{array}$} & \multicolumn{5}{|c|}{ Panelis } & \multirow{2}{*}{ Jumlah } & \multirow{2}{*}{ Rerata } & \multirow{2}{*}{ Jlh-k } & \multirow{2}{*}{ Validitas } & \multirow{2}{*}{ Ket } \\
\hline & 1 & 2 & 3 & 4 & 5 & & & & & \\
\hline 1 & 4 & 5 & 4 & 5 & 4 & 22 & 4.4 & 17 & 0.85 & Valid \\
\hline 2 & 5 & 4 & 5 & 5 & 5 & 24 & 4.8 & 19 & 0.95 & Valid \\
\hline 3 & 4 & 3 & 4 & 5 & 4 & 20 & 4 & 15 & 0.75 & Valid \\
\hline 4 & 5 & 4 & 5 & 3 & 3 & 20 & 4 & 15 & 0.75 & Valid \\
\hline 5 & 3 & 3 & 5 & 5 & 5 & 21 & 4.2 & 16 & 0.8 & Valid \\
\hline 6 & 5 & 5 & 5 & 4 & 4 & 23 & 4.6 & 18 & 0.9 & Valid \\
\hline 7 & 5 & 5 & 5 & 5 & 3 & 23 & 4.6 & 18 & 0.9 & Valid \\
\hline 8 & 4 & 4 & 4 & 4 & 5 & 21 & 4.2 & 16 & 0.8 & Valid \\
\hline 9 & 5 & 5 & 4 & 4 & 4 & 22 & 4.4 & 17 & 0.85 & Valid \\
\hline 10 & 5 & 3 & 5 & 5 & 5 & 23 & 4.6 & 18 & 0.9 & Valid \\
\hline
\end{tabular}

Hasil perhitungan penilaian validator terhadap butir/komponen instrumen Tes Hasil Belajar, menunjukkan bahwa dari 5 orang validator memberikan penilaian terhadap Media Pembelajaran diperoleh butir 1,3,5,6,7,8,9, dan 10 diiinterpretasikan "sangat sesuai" dengan rentang nilai 4,20 - 4,80. Kemudian butir 3 dan 4 diinterpretasikan " sesuai " dengan rerata nilai 4,00.

Hasil analisis validitas isi setiap butir yang dihitung dengan menggunakan rumus Aiken, diperoleh bahwa indeks validasi semua butir antara 0,75-0,95 dengan kesimpulan "Valid".

Hasil analisis ini kemudian diperkuat dengan hasil perhitungan kekonsistenan penilaian panelis yang diperoleh dari koefisien reabilitas yaitu sebesar 0,99. 
Gubali, M.M. et al. / Jambura Physics Journal (2021) Vol. 3 (1): 24-41

Hasil Pengamatan Kegiatan Pembelajaran

Untuk mengamati kegiatan proses pembelajaran yang dilaksanakan di kelas, digunakan lembar pengamatan yang terdiri dari 45 aspek.

Berdasarkan pengamatan yang dilakukan observer 1 dan observer 2, diperoleh hasil seperti nampak pada tabel 15 dan 16 berikut.

Tabel 15. Data Hasil Observer 1 terhadap Pelaksanaan Pembelajaran

\begin{tabular}{ll}
\hline Kegiatan & $\begin{array}{l}\text { Persentase capaian } \\
\text { Kualitas pembelajaran }\end{array}$ \\
\hline Pertemuan 1 & 92.35 \\
Pertemuan 2 & 92.25 \\
Pertemuan 3 & 92,45 \\
\hline
\end{tabular}

Berdasarkan tabel 15, nampak bahwa keterlaksanaan pembelajaran, baik pertemuan 1 sampai dengan pertemuan 4 rata- rata mencapai 92,35\%. Hal ini menunjukkan bahwa seluruh kegiatan guru dalam proses pembelajaran telah terlaksanakan dengan sangat baik.

Tabel 16. Data Hasil Observer 2 terhadap Pelaksanaan Pembelajaran

\begin{tabular}{ll}
\hline Kegiatan & $\begin{array}{l}\text { Persentase capaian } \\
\text { Kualitas pembelajaran }\end{array}$ \\
\hline Pertemuan 1 & 90 \\
Pertemuan 2 & 91,76 \\
Pertemuan 3 & 90,58
\end{tabular}

Berdasarkan tabel 16, nampak bahwa keterlaksanaan pembelajaran, baik pertemuan 1 sampai dengan pertemuan 3 rata- rata mencapai 90,78\%. Hal ini menunjukkan bahwa seluruh kegiatan guru dalam proses pembelajaran dengan menngunakan perangkat pembelajaran yang telah dikembangkan dengan Model ADDIE telah terlaksana sesuai tuntutan. Jadi dapatlah disimpulkan,bahwa proses pembelajaran yang dikelola oleh guru dengan menggunakan langkah - langkah pembelajaran suda tercapai. Pencapain ini menandakan efektifitas penggunaan perangkat yang dikembangkan

Penelitian ini bertujuan untuk menghasilkan perangkat pembelajaran IPA Terpadu yang layak dan efektif digunakan dalam pembelajaran. Penelitian pengembangan perangkat pembelajaran ini dilakukan melalui beberapa tahapan kegiatan berdasarkan model pengembangan ADDIE.

Hasil penelitian menunjukkan bahwa, perangkat pembelajaran yang telah dirancang peneliti dan divalidasi oleh para ahli diperoleh hasilnya berupa perangkat pembelajaran yang valid dan reliabel dengan kesimpulan sangat layak digunakan. Hasil validasi yang telah dilakukan oleh para ahli ini berupa saran atau masukan yang disertai penilaian terhadap masing-masing perangkat. Saran atau masukan para ahli atau panelis diolah secara statistik untuk dijadikan dasar pengambilan keputusan apakah perangkat tersebut valid dan reliabel. Oleh sebab itu, model ini dapat digunakan untuk berbagai macam bentuk pengembangan 
Gubali, M.M. et al. / Jambura Physics Journal (2021) Vol. 3 (1): 24-41

produk seperti model, strategi pembelajaran, metode pembelajaran, media dan bahan ajar.

\section{Kesimpulan}

Hasil Pengembangan Perangkat Pembelajaran IPA Terpadu dengan Model ADDIE pada materi Energi dalam Sistem Kehidupan meliputi Silabus, RPP, LKPD, Bahan Ajar dan Tes Hasil Belajar memenuhi syarat valid, serta reliable, karena hasil uji coba telah memenuhi unsur-unsur dengan interpretasi penilaian validator atau panelis sangat sesuai dan sesuai.

\section{Referensi}

Affandi, M. (2011). Penelitian Tindakan Kelas. Bandung: Alfabeta.

Anderson, Lorin W \& David, K. (2010). A Taxonomy for Learning Teaching and Assessing A Revision of Blooms Taxonomy of Education Objectives. New York: Addison Wesley Longman, Inc.

Angel, L. (2008). Instructional design in ANGEL. Artikel. Tersedia pada http://www.angellearning.com. [1 Januari 2019].

Daryanto. (2010). Media Pembelajaran. Yogyakarta: Gava Media. Kemendikbud, 2014. Materi Pelatihan Impelemntasi Kurikulum 2013.

Depdiknas. (2003). Undang-undang RI No.20 tahun 2003 tentang Sistem Pendidikan Nasional. Depdiknas,2006

Depdiknas. (2003). Pembelajaran Cooperative Learning.Jakarta.Kementerian Pendidikan Nasional.

Depdiknas. (2006). Peraturan Menteri Pendidikan Nasional Republik Indonesia Nomor 22 Tahun 2006 Tentang Standar Isi untuk Satuan Pendidikan Dasar dan Menengah Lampiran 2 Standar Kompotensi dan Kompotensi Dasar Tingkat SMP-MTs-SMPLB. Jakarta: Dirjen Dikdasmen.

Depdiknas. (2008). Pengembangan Bahan Ajar.Direktorat Pembinaan Sekolah Menengah Atas dan Direktorat Jenderal Manajemen Pendidikan Dasar dan Menengah Departemen Pendidikan Nasional.

Fathurohman, M. (2015). Model-model Pembelajaran Inovatif.Yogyakarta: Ar.Ruzz Media.

Hamalik, U. (2007). Proses Belajar Mengajar. Jakarta: Bumi Aksara Soetomo.

Hoetawarman,W. (2001). "Peningkatan Keterampilan Proses Melalui Model Pembelajaran Kooperatif Tipe STAD pada Konsep Keseimbangan Kimia di Kelas 2 Cawu 1 SMUN". 
Tesis. Universitas Negeri Surabaya.

Hudoyo, H. (1988). Teori Dasar Belajar Matematika.Jakarta: Direktorat Jenderal Pendidikan Tinggi.

Italismaya F. (2007). "Pengembangan Perangkat Proses Belajar Mengajar Berorientasi Kecakapan Hidup (life skill) pada Materi Sistem Reproduksi Manuasia". Skripsi. Universitas Negeri Surabaya.

Komara, E. (2014). Belajar dan Pembelajaran Interaktif.Bandung:PT Refika Aditama

Majid, A. (2011). Perencanaan Pembelajaran. Bandung: PT. Remaja Rosdakarya.

Molenda, M. In search of the ellusive ADDIE model. Pervormance improvement, 42(5), 34 - 36. Submitted for publication in A. Kovalchick \& K. Dawason, Ed's, Educational Technologi: An Encyclopedia. Copyright by ABC-Clio, Santa Barbara, CA, 2003. (http://www.indian.edu). [25 Desember 2019].

Mudhofir. (1990). Teknologi Instruksional. Bandung: Remaja Rosdakarya.

Nieveen, N. (1999). Design Approaches and Tools in Education and Training-Prototyping to Reach Product Quality. Dordrecht : Kluwer Academic Publisher.

O'Meara. (2000). Perangkat Pembelajaran (https://anrusmath.wordpress.com). [29 September 2019].

Permendikbud No.54 Tahun 2013 tentang Standar Kompetensi Lulusan Pendidikan Dasar dan Menengah.

Permendikbud No.58 Tahun 2013 tentang Kerangka Dasar dan Struktur Kurikulum Sekolah Menengah Pertama/MTs.

Permendikbud No.64 Tahun 2013 tentang Standar Isi Pendidikan Dasar dan Menengah.

Permendikbud No.65 Tahun 2013 tentang Standar proses Pendidkan Dasar dan Menengah.

Permendikbud No.66 Tahun 2013 tentang Standar Penilaian Pendidikan Dasar dan Menengah.

Permendikbud No.81a Tahun 2013 tentang Impelementasi Kurikulum 2013.

Permendiknas. (2007). Standar Proses Pembelajaran. Jakarta: Glosarium.

Pribadi, B. A. (2009). Model Desain Sistem Pembelajaran. Jakarta: Dian Rakyat

Robert. (2003). Pengembangan Pembelajaran Berbasis Blended Learning pada Mata Kuliah 
Gubali, M.M. et al. / Jambura Physics Journal (2021) Vol. 3 (1): 24-41

Pemrograman Komputer (Studi Kasu: UNISDA Lamongan) N Barokati,F Annas Sisfo Vol 4 NOS 2013-.is-its.ac.id.

Rohani. (2013). Tesis, Pengembangan Perangkat Pembelajaran Matematika Kelas VII Berdasarkan Model Dick and Carey. UNG.

Rohman, M. Amri, S. (2013). Strategi dan Desain Pengembangan Sistem Pembelajaran. Jakarta. Pustaka Raya

Sadiman. (1986). Media Pendidikan.Media Peta Puzzle.

Sagala, S. (2010). Konsep-konsep dan Makna Pembelajaran.Bandung: Penerbit Alfabeta.

Slavin, R. E. (2000). Educational Psychology Theory In to Practice. Edisi 6. Boston: Allyn \& Bacon.

Soetopo, H. (2005). Pendidikan dan Pembelajaran. Bandung: UMM Press.

Sudjana. (2004). Dasar-dasar Proses Belajar Mengajar. Bandung: Sinar Baru Algensindo.

Sugiyono. (2007). Statistika untuk Penelitian. Bandung: Alfabeta.

Suharsimi, A. (1992). Dasar-dasar Evaluasi Pendidikan. Penerbit Bumi Aksara.

Suparno, P. (2002). Reformasi Pendidikan.Yogyakarta: Kanisius.

Suyono. (2004). Perangkat Pembelajaran. Makalah yang disampaikan pada acara TOT Guru Sains SD se Jawa Timur. Kanwil Pdan K Propinsi Jawa Timur.

Trianto. (2010). Mendesain Model Pembelajaran Inovatif-Progresif. Jakarta: Kencana Prenada.

Wahyuni. (2005). Penerapan kecakapan hidup (life skills) untuk meningkatkan prestasi belajar PPKn pada siswa tuna netra kelas IV di SLB-A YPAB Surabaya. Tesis. Universitas Negeri Surabaya. 